\title{
Technological Unemployment and Its Educational Discontents
}

\author{
Petar Jandrić and Sarah Hayes \\ Zagreb University of Applied Sciences and University of Wolverhampton
}

\section{Introduction}

Tool-making is one of the key defining features of humanity. Our relationships to various kinds of tools define the historical progress of our species (Stone Age, Bronze Age, Industrial Revolutions), our social organization (Marx \& Engels 1976) and, with the advent of the Anthropocene, our relationship to nature (Jandrić 2017). Ancient tools, such as a stone knife or hammer, are of an individual nature-it takes one person to make, use and dispose of them. However, at least since the Industrial Revolutions, tools have grown much more complex; these days, it takes thousands of people to design, produce and dispose of a 'simple' smartphone that any 3-year-old can use. The collective nature of modern technologies has strongly contributed to the organization of society including, but not limited to, the division of labour. Primitive tool-making of the past has become the technique of the present-the social, economic and technological way of arranging our daily affairs (see e.g. Ellul 1964; Stiegler 1998; Horkheimer \& Adorno 2002). With the advent of computers, digital

How to cite this book chapter:

Jandrić, P., \& Hayes, S. (2020). Technological unemployment and its educational discontents. In M. Stocchetti (Ed.), The digital age and its discontents: Critical reflections in education (pp. 161-182). Helsinki: Helsinki University Press. https://doi .org/10.33134/HUP-4-9 
technologies have permeated human lives and this has inspired development of a more nuanced postdigital approach to relationships between human beings and technologies. 'The postdigital is hard to define; messy; unpredictable; digital and analog; technological and non-technological; biological and informational. The postdigital is both a rupture in our existing theories and their continuation' (Jandrić et al. 2018: 895). The postdigital challenge is equally about the ability 'to understand the processes of quantum computing, complexity science, and deep learning as they constitute the emerging techno-science global system and its place within a capitalist system that itself is transformed by these developments' (Peters \& Besley 2019: 40) and about 'making at least a small leap from the standard academic paradigm of individual knowledge development towards new forms of collective intelligence' (Jandrić 2019: 2). It is within the postdigital paradigm that this chapter enquires into the relationships between technological unemployment and its educational discontents.

One of the key promises of technology is the world without work: a utopian vision, where people do what they please while machines do all (or most) of the daily work for us. Historically, this promise has been explored in fictional and semi-fictional domains such as science fiction and futurism. However, the increasing digitization and automatization of jobs which had up until yesterday been reserved for humans - such as driving, curing people and academic research-has turned these fictional accounts into possible future scenarios (see, for instance, Peters 2017; Peters \& Jandrić 2018a; Peters, Jandrić \& Means 2019). The promise of technological unemployment is not all sunshine and roses. Actually, at least since the proverbial 18th-century weaver Ned Ludd smashed his two knitting frames in a 'fit of passion' (Alsen 2000: 43), people have strongly opposed the idea of replacing their work with machines. One of the major arguments for such Luddite fear of technology was the loss of jobs; however, technologies of the past have always somehow managed to create more jobs than they destroyed.

Recent research indicates that digital technologies of today may be different. Some authors think that we have arrived at a sort of Fukuyamian (1992) 'end of history' where digital technologies have finally started to destroy more jobs than they create (Brynjolfsson \& McAfee 2011; Frey \& Osborne 2013; Frey \& Osborne 2015). Others are more careful and claim that we have no right to that type of historical exceptionism-while they cannot explain exactly how digital technologies might create more jobs than they erase, they have faith in the old saying that history will somehow repeat itself (MacCarthy 2014; Summers 2014). Currently, we do not have enough information to take sides in this debate. This implies that we need to carefully examine three possible scenarios: (1) the future where digital technologies will create roughly an equal number of jobs as they will destroy; (2) the future where digital technologies will create more jobs than they will destroy; (3) the future where digital technologies will destroy more jobs than they will create. However, the first scenario and the second scenario have repeated many times, while the third scenario is still an open 
book. In this chapter, therefore, we examine an imagined future where digital technologies will destroy more jobs than they will create.

We examine negative projections of such a future and its educational aspects in three steps. We first undertake an extensive literature review to identify the main reasons why people from various historical periods and working in various fields have perceived technological unemployment as a threat. We then move on to explore an overview of contemporary concerns based on our recent work (Peters, Jandrić, \& Means 2019). Finally, we examine educational discontent of technological unemployment as an agent of change.

\section{The Luddite Fantasy?}

While historically, waves of technological advancement and demographic change have led to increased prosperity, productivity and job creation, this does not mean these transitions were free of risk or difficulty (World Economic Forum 2016).

Since the dawn of the industrial age, a recurrent fear has been that technological change will spawn mass unemployment. Neoclassical economists predicted that this would not happen, because people would find other jobs, albeit possibly after a long period of painful adjustment. By and large, that prediction has proven to be correct. (Rogoff 2012)

Rogoff adds that, although there have been problems of inequalities and wars, 'two hundred years of breath-taking innovation since the dawn of the industrial age have produced rising living standards for ordinary people in much of the world, with no sharply rising trend for unemployment' (2012). Across much (but not all) of the world, people now live longer, work many fewer hours and lead healthier lives. All good arguments for technological progress then, but does this mean that a historical fear of machines versus human labour was wrong? When, in 1812, textile-making machines at the dawn of the Industrial Revolution were smashed in the belief that these new contraptions would put hand-weavers out of work, were such worries unfounded and is the end-of-work argument simply the Luddite fallacy?

Thompson (2015) suggests we should not drop these concerns too quickly. Some economists are now beginning to worry that the Luddites were not wrong, just premature (Krugman 2013; Skidelsky 2013; Skidelsky 2014; Thompson 2015). However, Skidelsky (2014) reminds us that David Ricardo, the most influential economist of the 19th century, was stating precisely this, in his chapter on machinery in On the principles of political economy and taxation (1817). Ricardo, discussing the substitution of machines for human labour, commented that the 'same cause which may increase the net revenue of the country, may at the same time render the population redundant' and therefore 
the opinion entertained by the laboring class, that the employment of machinery is frequently detrimental to their interests, is not founded on prejudice and error, but is conformable to the correct principles of political economy. (Ricardo 1817)

If this is the case, then Martin Ford, in The rise of the robots: technology and the threat of a jobless future, takes us forward from the Industrial Revolution to the present day by providing a simple hypothetical technology narrative that expands on the eras that have followed. Ford discusses the golden era from 1947 to 1973 , as characterized by significant technological progress and strong productivity growth, where innovations were primarily mechanical, chemical and in aerospace engineering. Soaring productivity during this time period made workers more valuable-and allowed them to command higher wages (Ford 2015: 51). Then, in the 1970s, productivity fell, as the economy received a major shock from the oil crisis and entered an unprecedented period of high unemployment combined with high inflation and a lower rate of innovation, as continued technological progress became more difficult. The 1980s, however, saw increased innovation, focused now in the information technology sector. Ford suggests that this type of innovation had a different impact on workers: for those with the right skill set, computers increased their value, just as the innovations in the post-war era had done for nearly everyone (ibid.: 51). For others, though, it meant their jobs were destroyed or deskilled, making these workers less valuable, until they were able to retrain for jobs that leveraged computer technology (ibid.: 52).

The 1990s then saw IT innovation accelerate even more, with the Internet taking off widely in the second half of the decade. Ford suggests that trends that began in the 1980s continued, but the decade also saw creation of millions of new jobs, especially in the IT sector. The recession of 1990-1991 was followed by a jobless recovery as workers, many of whom had lost good midrange jobs, struggled to find new positions. The job market gradually became more polarized and, in the years following 2000, information technology continued its acceleration. Productivity rose, as businesses became better at taking full advantage of new innovations (Ford 2015: 52). Throughout the economy, computers and machines were increasingly replacing workers, rather than making them more valuable, and wage increases fell far short of growth in productivity, with jobless recoveries becoming the norm (ibid.: 52). This simple account is intended by Ford not to downplay other factors such as globalization, the growth of the financial sector and other political changes, but to emphasize the consistent role of technology within these changes.

Avent (2016) picks up this tale in The wealth of humans, where he describes the present as a troubling political moment, which our failure to recognize and address the difficulties created by the digital revolution has ushered us into. Avent suggests the digital revolution is: 
Putting us into the shoes of our great-great-grandparents: those who first experienced the transmission of a human voice across an electrical wire, who watched as the time to travel from one city to a distant other shrank from weeks to hours and who found themselves displaced as smiths or farmhands by fantastic new technologies. We have all found our working lives altered by it. (ibid.:2)

An important difference can be noted here though. Where the Industrial Revolution unfolded over centuries, our current technology revolutions are happening over years. The technologies of the future are those of the 2020s and therefore significant changes to the world of work are no longer distant, but imminent. Avent argues that the digital revolution alters work in three ways: first, through automation, as new technologies replace a range of workers; second, globalization has become supercharged through powerful information technology; and, third, technology massively boosts the productivity of some highly skilled workers, enabling fewer people to achieve what would once have taken very many more humans to accomplish. Therefore, automation, globalization and the rising productivity of a few are combining to generate an abundance of labour: a wealth of humans (Avent 2016). The global economy, according to Avent, is now misfiring in worrying ways, as it tries to digest unprecedented conditions that are disrupting our world. Work, alongside family, is a crucial aspect of social infrastructure that can no longer be counted on to fulfil the range of roles we have for so long attributed to it. From ordering the day, providing purchasing power and contributing to the community, as these factors can no longer be taken as given, Avent suggests something will have to give, as we struggle to find substitutes. So, is the substitute really a world without work?

Historically, this utopian vision has once resided in the imagination of writers and directors of movies. While technology is indeed not destiny (Feenberg 2002), technological development often feels as though it is the main factor determining the direction that we move in. Science fiction offers us a route to imagine how society could function differently, in both good or bad ways, increasing our awareness of futures we might want to avoid, or indeed those we might want to progress towards. For example, in Brave new world, Aldous Huxley (1932) envisages a dystopian world where technology might take us in the future, with routine genetic engineering and elimination of unhappiness. His story has since been considered to be prophetic. Later, in Huxley's Island (1962), inhabitants have for 120 years resisted capitalism, consumerism and technology. Then there are movies that introduce technologies that just a few years later are here in reality. For example, to create the high-tech world of 2054 for sci-fi blockbuster Minority report, director Steven Spielberg (2002) consulted with an expert team of futurists, including computer scientists, philosophers, artists and architects, with the wish for the toys he featured to come true. The movie, released in 2002, portrayed multi-touch interfaces and retina 
scanners that are now routinely in use and the film has inspired many entrepreneurs and companies to innovate (Chung 2014).

Although a common theme is a world where humans do less work and machines do more, which should be a good problem to have, the prospect of this becoming a reality in the same way as a touch screen seems often to be met with controversy or it is studiously ignored. Falkner questions why, when machines have been saving humans time for decades, we have not yet reached a leisure-oriented future (2017). Referring to implications of block chain technologies for international trade that can automate work that was manual and error-prone, bringing benefits with less human labour, Falkner believes we will soon see a real reduction in human work, as promised for decades. He reminds us that John Maynard Keynes in 1930 suggested we would be working 30 hours a week by 2030 and our problem would be too much free time. Yet, during the 1980s, working harder, for longer, somehow became desirable and demandable by employers (ibid.). This brings into play interesting questions. Technological advancement and the way we tend to think about work are at odds if the amount of work we do defines our value as humans. Falkner argues that overwork is often interpreted as commitment rather than inefficiency, and judgments are made about those who work less. Yet, visions of a reduced working week were once visions of a more effective workforce. Then, additionally, few governments will want to cause widespread unemployment as this is understood as linked to social and economic issues (ibid.).

With these two significant concerns to consider, we question whether science fiction has some role to play in helping to begin to alter such perceptions. Menadue and Cheer (2017) suggest that fiction can provide common ground for researchers to engage with the public across a wide range of disciplines, providing advocacy and cultural insight and also acting as an aid to learning and teaching. These are important considerations given arguments about potential political unrest following a scarcity of work and suggestions that saving work is more important than saving any particular job (Thompson 2015). Similarly, McKenzie Wark says:

It is commonplace that science fiction is not about the future, but about alternative possible presents. Science fiction is one of the things that enables you to think through relationships between different kinds of knowledge ... Science fiction is not always about science, some works actually ignore the science, but it is usually about a geopolitical reality. (Jandrić 2017: 132)

Avent (2016) argues that the hardest part in finding utopia is not the figuring out of how to produce more; we have already managed that. The hard part is redistribution and sustainability when the rich don't want to subsidize the poor. He points to problems though too if we adopt a 'makers-and-takers' conception of the world, because this neglects the social foundation on which wealth is 
built. Thompson (2015: 11) points to the role played by work in people's selfesteem, suggesting the prospect of a no-work future seems hopeless. Yet, a future of less work he believes still holds a glint of hope, because the necessity of salaried jobs now prevents so many from seeking immersive activities that they enjoy. This raises further questions that we intend to explore in future research alongside the societal trends brought to our attention by George Ritzer, including McDonaldization and digital prosumer capitalism (Ritzer, Jandrić \& Hayes 2018).

Building a post-work society is a pressing project that cannot be ignored. We are no longer smiling at science fiction because machines that replace us are here to drive our cars and land our planes. So can we, as Srnicek and Williams suggest, fully automate the economy, reduce the working week, implement a universal basic income and achieve a cultural shift in the understanding of work (2015: 108)? That remains to be seen, but Falkner stresses the need to work out how to support people in a post-work economy and to accurately identify which jobs machines can't do. Given that we now live in the age predicted by science fiction, will we choose to give ourselves leisure, or not (Falkner 2017)?

\section{Educational Discontent of Technological Unemployment}

At the moment of writing this chapter, we have just submitted a draft manuscript for an edited book entitled Education and technological unemployment (Peters, Jandrić \& Means 2019). Consisting of 23 chapters, the book displays a wealth of perspectives and debates about the theme. While we peer-reviewed chapters for Education and technological unemployment, we identified six main areas of discontent: discontent with neoliberalization, discontent with automation, discontent with dehumanization, discontent with acceleration, discontent with content of work, and discontent with educationalization. While this list is far from analytic, it does offer a good glimpse into collective concerns of scholars working in the field. In the following sections, we briefly analyse each of these areas.

\section{Discontent with neoliberalization}

Since the 1980s, much has been written about neoliberalization of education (see Peters \& Jandrić 2018b; Peters \& Jandrić 2018c). In brief, these writings describe dissolving of The Public University circa 1960-1980, which 'views free higher education as a fundamental human right and a necessary institution for assuring the participation of workers in the global knowledge economy, for countering technological unemployment, and for creating informed citizens within a democracy' (Peters \& Jandrić 2018c: 554), and its replacement by the Neoliberal University. 
This model shifts core commitments of the university from 'the quest for universal truth' and 'the cultural infrastructure for democracy' to 'quality assurance' as defined by the discourse of efficiency and excellence, where neoliberal managerialism becomes the dominant model of knowledge performance. Structural transformation towards the 'knowledge economy' is supposed to follow from the production of knowledge, investment in human capital and the diffusion of information and communication technologies requiring 'management. Neoliberal knowledge management rests on principles of homo economicus (assumptions of individuality, rationality and self-interest) that are radically at odds with distributed knowledge systems. (Peters \& Jandrić 2018c: 554)

This philosophical and structural shift has produced dire consequences for employment in the higher education sector. According to Forbes:

In 1975, 30 percent of college faculty were part-time. By 2011, 51 percent of college faculty were part-time, and another 19 percent were non-tenure track, full-time employees. In other words, 70 percent were contingent faculty, a broad classification that includes all nontenure track faculty (NTTF), whether they work full-time or part-time. (Edmonds 2015)

While this statistic covers only the United States, similar trends are identified all around the world (Peters \& Jandrić 2018b: ch. 3).

The Neoliberal University causes different types of discontent. From a student perspective, excessive reliance on adjunct work lowers the quality of instruction-overworked, underpaid and often without their own offices where they could see students, many adjuncts are simply unable to meet student needs (Ginsberg 2010). From a staff perspective, adjunct work is associated with poverty, job insecurity, lack of long-term career prospects and the lack of tenure protection, which results in inability to take on difficult topics in their classes (ibid.). From a social perspective, the Neoliberal University restricts upward mobility and promotes inequality. The commodified Neoliberal University sees knowledge and education as goods that can be sold and bought, and significantly reduces the public sphere (Peters \& Jandrić 2018c). The Neoliberal University is supported by digital technologies, which enable practices such as automated testing and surveillance. More importantly, however, the Neoliberal University is based on powerful, rationalist logic in policies that might appear convincing, but when scrutinized, the discourse can lean towards irrationality (Hayes 2018; Hayes 2019) Furthermore, the success of educational systems is measured and evaluated predominantly though quantitative means-and the use of this or that technology is only a symptom of a wider ideological trend of McDonaldization of higher education (Ritzer, Jandrić \& Hayes 2018). 


\section{Discontent with automation}

Much has been written about the perils of positivist educational science, yet this has not prevented neoliberal policymakers placing increasing trust in data-a move that has stripped the Neoliberal University of many humanistic values in the process of implementing New Public Management policies of various hues and colours (Peters \& Jandrić 2018b: 38). Unsurprisingly, the rising importance of data has implications for ownership over data. In line with an overall commodification of higher education, Ben Williamson shows that data about students and staff in worldwide institutions is predominantly collected and processed in the commercial sector. This transfer of ownership has profound consequences for teaching, learning and research:

The central argument is that as educational data science has migrated from the academic lab to the commercial sector, ownership of the means to produce educational data analyses has become concentrated in the activities of for-profit companies. As a consequence, new theories of learning are being built-in to the tools they provide, in the shape of algorithm-driven technologies of personalization, which can be sold to schools and universities. (Williamson 2017: 105)

Datafication of higher education is often justified by claims to fairness and equal opportunity (Koltay 2015). However, this cannot be further from the truth, as large datasets characteristic for higher education, such as results of student performance on standardized tests, are far from neutral. A telling example is Cormac O'Keeffe's analysis of 'the role of various psychometric practices and testing theories, in particular item response theory, and their ability to link literacy practices and calculable psychological constructs'. O'Keeffe's research 'suggests that large-scale digital assessments such as PIAAC do not merely produce data about ability-more importantly, they "perform the concept of ability into being"' (O'Keeffe 2017: 133). Data is biased, because datasets reflect values and ideologies of their collectors. Furthermore, shows Jones, 'the complex systems of data production and representation co-constitute the very systems they purport to describe' (Jones 2018: 49). Upon collection, intrinsically biased datasets are processed by various artificial intelligence (AI) tools.

According to Liza Daly, 'artificial intelligence is the umbrella term for the entire field of programming computers to solve problems. I would distinguish this from software engineering, where we program computers to perform tasks.' This simple definition describes an important paradigm change in inner workings of the computer. Traditional computers, including the most sophisticated expert systems of yesterday, consisted of long lines of code which determined their behaviour: for every input, such systems would do predetermined calculations and provide an output. In contrast, AI systems are provided with some initial rules of behaviour, and then they are 'taught' by large datasets. Then, computer 
independently establishes various connections between input data and produces 'intelligent' solutions to new problems in non-predetermined ways. This is the essence of machine learning, which is broadly defined as 'the science of getting computers to act without being explicitly programmed' (Jandrić 2019)

In the process of machine learning, data bias develops towards AI bias. Resulting from non-predetermined 'thinking', the AI bias is very difficult to detect and even more difficult to remove. In a recent example, Amazon developed an AI recruitment software and 'taught' the software using its own human resources archives. However, the AI showed strong bias against women, and after many attempts at fixing the problem, researchers gave up and scrapped the AI recruiting tool completely (Dastin 2018). Data bias and AI bias are currently being addressed by practices such as algorithm auditing. However, auditing arrives into play only after an algorithm is developed, and 'an audit doesn't prove that a company has avoided all the unintended pitfalls of an algorithm. The auditor might not look at the right set of stakeholders, or pose the right set of questions' (Hempel 2018). Unsurprisingly, such (lack of) solutions provide(s) a significant amount of discontent, and even for-profit capitalist giants such as IBM claim that 'it's critical to develop and train these systems with data that is unbiased and to develop algorithms that can be easily explained' (IBM Research 2018).

\section{Discontent with dehumanization}

Since the beginning of the so-called digital revolution (an imprecise term, which we use here only for its face value), people have argued that digital technologies are inferior to their analogue counterparts. For instance, many audiophiles claim that old gramophones played on valve amplifiers provide 'warmer' and 'fuller' sound than digital CDs; as of recently, old gramophone records have returned with a vengeance (Meyer 2009). Claims to computerized dehumanization are based on similar claims to superiority of the analogue over the digital, but consequences of such superiority are now much more extensive. In Automating inequality: how high-tech tools profile, police, and punish the poor, Virginia Eubanks (2018) outlines the history of automation within social services. She shows that (provision of) social services has always dehumanized the poor, yet automation of these services has brought such dehumanization to unprecedented levels. Eubanks shares sad stories of people who have been denied adequate health care based on decisions of computers, and of new administrative systems in which people are unable to revert automated decisions-more often than not, there is not even a human being who could listen to the complaints. Eubanks thus develops the notion of 'the digital poorhouse', which uses technological tools to control the lives of poor people to an unprecedented extent:

Addressing the digital poorhouse can help progressive social movements shift attention from 'the police' to the processes of policing. 
Policing is broader than law enforcement: it includes all the processes by which we maintain order, regulate lives, and press people into boxes so they will fit our unjust society. The county poorhouse was an extrajudicial institution, built to imprison those who were not guilty of any crime. Scientific charity policed the lives of poor and working-class people for two generations, with brutal results. Today, the digital poorhouse uses its high-tech tools to infer and predict: to police events that haven't even happened yet. (Eubanks 2018: 179)

Similar concerns can be found in literature covering the Chinese Social Credit System where, according to Wired, 'Big data meets Big Brother as China moves to rate its citizens' (Botsman 2017). And similar accounts of technological dehumanization all over the world fill headlines of today's media. According to Gabriella Coleman, dehumanization is not built into technologies; instead, it results from interaction between technology and social organization (Coleman \& Jandrić 2019). Focusing on technological agency, discontent with dehumanization is especially prominent in the fields of sociomaterialism, networked learning and similar (Jandrić 2017: ch. 9).

Another prominent form of discontent with technological dehumanization is linked to the impact 'of increasing digital connectedness and how this connectivity might affect the culture of learning now, and in the future' (Falconer 2019: 244). Reviewing Maggi Savin-Baden's book Rethinking learning in an age of digital fluency: is being digitally tethered a new learning nexus? (2015), Falconer shows 'that tethering is, if not actually a pejorative term, at least a term that implies confinement and restriction rather than freedom' (Falconer 2019: 246). These concerns are often linked to privacy, and the idea that digitally tethered people can never leave their past behind. Furthermore, automation of occupations which involve direct contact with people, such as health care and care of the elderly, also often appear in dehumanization debates, and provoke a mixed bag of responses (Frude 2019).

\section{Discontent with acceleration}

At least since Filippo Tommaso Marinetti and his 'Manifesto of futurism' (1919), speed and its connection to machinery has been praised and cursed in almost equal measure. From Deleuze and Guattari (1988) to a hectic mix of right-wing accelerationists such as Nick Land (2014) and left-wing accelerationists such as Alex Williams and Nick Srnicek (2013), technologically inducted social acceleration is clearly linked to a mix of capitalism and technology. Applying accelerationist ideas to education and technological unemployment, Sam Sellar writes:

While accelerationism has been interpreted as wanting the worst, or as the worst kind of nihilism, its unconditional variants both prompt 
reconsideration of educational purposes and practices and suggests a minimal yet consequential shift in educational thought. Rather than asking what should be done educationally, in order to save society from the risks of technological unemployment, accelerationism prompts us to ask: How far can we go in letting go of the desire for education to solve such problems? (Sellar 2019: 142)

In this way, Sellar's critique brings the debate towards educationalization, which we explore a little later in this chapter.

Acceleration is a prominent theme in studies of (academic) time. As Crary has observed of human sleep: 'nothing of value can be extracted from it!' (2013: 11). Well, sleep perhaps bears no economic value in its own right, claims Lydia Rose, but the health consequences of lack of sleep are real. Combining academic insights into the figure of the cyborg (e.g. Haraway 1991) with fictional insights embodied in the Borg (the fictional character from Star trek: first contact (1996)) and in Doctor Who (BBC 2006), Rose shows that the 'resistance is futile' attitude might be counterbalanced by the theory of cognitive dissonance (2015: 324). Here, Rose's analysis of acceleration arrives at very similar conclusions to those in Maggi Savin-Baden's study of digital tethering (2015). However, not everyone agrees with Savin-Baden (2015) and Rose (2015), and opinion is divided on the merits of slowness versus acceleration in higher education.

Consequently, acceleration of academic time causes opposed types of discontent. Some authors claim that slowness needs to return to academia, for individual reasons (decreased stress, personal well-being, etc.), social reasons (sleep as a basic human right) and improving the quality of academic work (only well-rested people can be truly creative) (Gill 2009; Hartman \& Darab 2012; Kahneman 2013). However, authors such as Filip Vostal (2013) claim that the academia also needs its 'accelerative moments' which are often connected to 'ninja-like productivity'. Yet, continues Vostal, perhaps neither of those is the real solution: 'Rather than choosing between the regressive ethic of slow scholarship on the one hand, or the time management productivity trainings on the other, academics may benefit from a more level-headed approach that emphasises autonomy over their use of time' (ibid.). Following Vostal's conclusion, both types of discontent with acceleration of (academic) time need to be understood in the context of, and in dialectical relations to, types of responses that people are able to offer in return.

\section{Discontent with content of work}

Immediately after it was published online, David Graeber's essay 'On the phenomenon of bullshit jobs: a work rant' (2013) went viral. In his essay, Graeber argued that more than half of jobs in diverse sectors from finance to public relations are useless, and if people suddenly stopped doing them, the world 
would remain the same. After a few years of research, Graeber published the book Bullshit jobs: a theory (2018), which elaborates this thesis in detail. 'Provisional Definition: a bullshit job is a form of employment that is so completely pointless, unnecessary, or pernicious that even the employee cannot justify its existence' (Graeber 2018). Graeber classifies bullshit jobs in five main categories. (1) 'Flunky jobs are those that exist only or primarily to make someone else look or feel important' (e.g. liftboys and receptionists). (2) Goons are 'people whose jobs have an aggressive element', such as the military and corporate lawyers. (3) Duct tapers jobs exist 'because of a glitch or fault in the organization'; they solve problems which ought not to exist. (4) Box tickers 'exist only or primarily to allow an organization to be able to claim it is doing something that, in fact, it is not doing. (5) Finally, taskmasters arrive in two categories: unnecessary superiors who manage things that need not be managed and superiors whose job is to produce unnecessary work for others (Graeber 2018).

Graeber's theory completely depends on people's personal insights; the only criterion for a bullshit job is that people feel that their job is useless. While this approach can be (and is) critiqued on many different grounds (see, for instance, Duncan 2018), bullshit jobs are increasingly present in higher education. In the publish or perish culture, academic careers strongly depend on publication. Therefore, it is very tempting to produce meaningless articles which only serve to increase one's number of publications; to divide articles into sequences; and to exchange references with authors of other equally useless articles to increase everyone's impact factors (Jandrić 2015). Also, the increasing importance of external funding implies that academics often tailor their research to meet funding criteria, usually in the direction of abandoning blue-skies research (Braben 2002). These practices, and social forces leading to these practices, cause a significant amount of discontent in the educational community (Jandrić 2017).

Another important class of bullshit jobs within the academia is within administrative positions. Numbers are stunning. In The fall of the faculty: the rise of the all-administrative university and why it matters, Benjamin Ginsberg shows that in US universities in the period 1975 to 2005, the number of full-time professors went up 51 per cent. In the same period, the number of administrators went up 85 per cent, and the number of other administrative staffers went up a staggering 240 per cent (Ginsberg 2010: 25). As a result, shows Ginsberg,

... universities are filled with armies of functionaries-the vice presidents, associate vice presidents, assistant vice presidents, provosts, associate provosts, vice provosts, assistant provosts, deans, deanlets, deanlings, each commanding staffers and assistants-who, more and more, direct the operations of every school. Backed by their administrative legions, university presidents and other senior administrators have been able, at most schools, to dispense with faculty involvement in campus management and, thereby to reduce the faculty's influence in university affairs. (ibid.: 2) 
Somehow, such bureaucratization of the higher education does not imply that professors and other academic staff are now free to dedicate themselves to their main tasks, teaching and research. On the contrary: during the past years, academic staff all over the world spend increasing amounts of time doing administrative tasks such as attending numerous meetings and writing plans and reports, and media outlets such as The Guardian are packed with their accounts of discontent (Tahir 2010).

\section{Discontent with educationalization}

Aoun, in Robot-proof: higher education in the age of artificial intelligence (2017), argues that a robot-proof model of HE needs to fundamentally refit the mental engines of students' minds and calibrate them with a creative mindset and elasticity to invent, discover or otherwise produce something society deems valuable (ibid.: xviii). And Aoun is hardly the only one seeking solutions to social problems such as employment in (higher) education. Already in 1995, David Tyack and Larry Cuban have written about the phenomenon of educationalization (1995). In a more recent piece, Cuban explains this tendency as follows:

What 'educationalising' means is transferring societal structural problems to the institution of schooling so individual students and teachers then become first, an easy target to blame, and second, responsible for solving the problem. For example, national health problems of smoking tobacco and drinking alcohol in the prior century got translated into school courses for youth about the physical and cognitive damages done by both drugs. Too many road accidents? Driver training and completing a safe driver's course for high school graduation became a schoolbased solution to a national problem. And as you pointed out in your question, the harnessing of schools to an increasingly high-tech economy means that children and youth are engaged early and persistently in using electronic devices so that they can easily fit into a high-tech workplace. (Cuban in Jandrić 2017: 13)

Currently, students are discussed in educational policies as if they were any other type of consumer, simply purchasing a product bearing instructions for the workplace, rather than benefiting also from the transformative potential university education offers for the whole of life (Hayes 2015). Furthermore, references to 'the student experience', 'the 'body' of the curriculum or 'the student body' as if these were fixed, unchanging entities is misleading (Hayes 2017). Repeated attempts to 'fix' a range of societal issues (such as student engagement, employability, sustainability, digital capabilities) by 'educationalizing' these into university strategies lacks careful consideration of changes, both in demographics across student populations, and in relation to predictions of 
impending technological unemployment in a digital age. In our recent paper, we explored educationalization of technological employment in depth and concluded:

The idea that education can resolve the problem of technological unemployment is a political construction which has by and large failed to deliver its promise. Instead of animistic attribution of agency to abstract concepts such as 'use of technology', 'strategy', 'framework' or even education at large, we should therefore give more agency to actual researchers, teachers, and students. Policy documents implicitly and explicitly draw from taken for granted visions of neoliberal social development and the associated understandings of concepts such as education, technology, and employment. In order to counter taken for granted visions, we need to reinvent these concepts, and the associated policy language, to include opportunity for radically different, non-supercessionist futures. Finally, we need to create new visions, and imagine different social orders, where concepts such as education, technology, employment may acquire radically different meanings. (Peters, Jandrić \& Hayes 2018)

Educationalization has many implications and purposes. According to Cole, educationalization 'entails the transformed economic relations of corporate capitalism'; 'calls into question the proper role of the state'; 'entails a futureoriented perspective towards time'; 'means a cultural revolution'; 'means a deep respect for science'; and 'entails an implicit (and at times explicit) utopianism' (Cole 2019). Widespread discontent with educationalization is hardly surprising, as many of these are implications and purposes are causes of discontent in themselves. In the education community, perhaps the biggest source of discontent is frustration-educationalizing social problems asks teachers to resolve problems which simply cannot be resolved within educational systems (Cuban in Jandrić 2017: 13).

\section{Discontent as an Agent of Change}

At the surface, sources of educational discontent with technological unemployment identified in our work seem to have surprisingly little to do either with technology or with employment. Discontent with neoliberalization is about the trend of diminishing rights of academic workers and its consequences. Sadly, in our educational systems, an obsession with treating students as competitive individuals and as a simple set of 'attributes' to bring to the global workforce (Peters, Jandrić \& Hayes 2018) has dominated recent policy. This is worthy of our collective rage at injustices in the contemporary social and political world order (McLaren 2006; McLaren 2015), but deciding who or what our rage is directed against may require a new global stream of consciousness. 
Discontent with automation, discontent with dehumanization, and discontent with acceleration are predominantly concerned with ways in which we use technologies, rather than technologies per se. Discontent with content of work, and more broadly discontent with educationalization of social problems, are pretty much non-technological questions. Furthermore, our distillation of some common sources of discontent from the edited book Education and technological unemployment (Peters, Jandrić \& Means 2019) inevitably results in imprecise and overlapping categories. For instance, a good part of discontent with acceleration is also discontent with dehumanization and educationalization, discontent with neoliberalization is present to various extents in all other categories, etc. These categories are only analytic tools which help us to get a better grasp of the problem: acting in synergy, their dialectical relationships produce the overall feeling of educational discontent with technological unemployment. Here, we see one more surfacing of Heidegger's idea that 'the essence of technology is by no means anything technological' (1981). Unlike our policymakers would want us to believe (Hayes 2015; Hayes 2017), technologies, education and work are parts of a wider techno-social system which cannot be understood by partial analyses.

Technological unemployment and its relationships to various human activities are not cast in stone-the human race had the power to develop a certain set of conditions that have created our present, and the human race has the power to develop a different set of conditions to create our collective future (see Feenberg 2002). Studies of technological unemployment need to embrace this dialectic between being and becoming (Dall'Alba \& Barnacle 2007); between where we are today and where we want to be in the future (Freire 1972). Arguably, education is one of the most powerful forces for creating conditions for the future of humankind. Therefore, our study advocates a significant change from mainstream, largely instrumental views towards education, with a view towards new directions, including those where we 'begin to teach people to do what machines cannot' (Aoun 2017: 19). While educational systems do prepare students for the marketplace, they also contribute to the creation of a (new kind of) marketplace. It is within this dialectic that we need to understand and explore the relationships between education and technological unemployment.

Discontent is a powerful force, which simultaneously makes people suffer unfavourable conditions and offers an incentive for change. In order to change a social phenomenon, however, one needs to identify what it is exactly that needs to be changed. And, in the post-digital mashup of the analogue and the digital, the physical and the biological, the technological and the political, it is often hard to see exact relationships between causes and consequences. The postdigital is indeed a rupture in our understanding of the world and its continuation (Jandrić et al. 2018: 895). Furthermore, claims Cox, 'the ruptures produced [by the postdigital] are neither absolute nor synchronous, but instead operate as asynchronous processes, occurring at different speeds and over different periods and are culturally diverse in each affected context' 
(2014). Conceived within postdigital circumstances, postdigital discontent is also asynchronous and culturally diverse-as such, it has the power to develop different answers and solutions. In order to change things, one needs to simultaneously think and act, and these two activities must continuously interact and enrich each other in the act of praxis.

According to our research, the notion of educational discontent with technological unemployment and its sources is far too nebulous to be addressed directly. This is why employment strategies produce meagre results at their best (Peters, Jandrić \& Hayes 2018; Hooley 2019), and this is where our breakdown of educational discontent with technological unemployment might be of use for rethinking and developing new forms of resistance. In the struggle against neoliberal (higher education) policies, we need to seriously take into account their relationships to technological unemployment; while we grapple with educational unemployment, we do need to understand its many faces, including but far from limited to, the human cost spelled out in dehumanization debates. Our study of educational discontent with technological unemployment is far too broad to develop into a well-defined critical rage pedagogy (McLaren 2006; McLaren 2015), especially in the style of its famous pre-digital proponents such as Malcolm X or its digital proponents such as Aaron Schwartz. Yet, it might provide some theoretical framing and some practical directions for picking the right target for our critical rage in the postdigital times to come.

\section{References}

Alsen, E. (2000). New romanticism: American fiction. New York: Routledge.

Aoun, R. (2017). Robot-proof: higher education in the age of artificial intelligence. Cambridge, MA: MIT Press.

Avent, R. (2016). The wealth of humans: work and its absence in the twenty-first century. London: Penguin.

BBC. (2006). Doctor Who. Season 2, Episode 14, 'Doomsday', daleks vs cybermen.

Botsman, R. (2017, 21 October). Big data meets Big Brother as China moves to rate its citizens. Wired. Retrieved from https://www.wired.co.uk/article /chinese-government-social-credit-score-privacy-invasion

Braben, D. W. (2002). Blue skies research and the global economy. Physica A, 314, 768-773. DOI: https://doi.org/10.1016/S0378-4371(02)01065-8

Brynjolfsson, E., \& McAfee, A. (2011). Race against the machine: how the digital revolution is accelerating innovation, driving productivity, and irreversibly transforming employment and the economy. Lexington, MA: Digital Frontier Press.

Chung, B. (2014). 13 movies that explore the future of technology. Motherboard, Vice. Retrieved from https://creators.vice.com/en_uk/article/53wgp5 /13-movies-that-explore-the-future-of-technology 
Cole, J. (2019). Antigonish, or an 'education that is not educationalization'. In R. Bruno-Jofré (Ed.), Educationalization and its complexities: religion, politics, technology. Toronto: University of Toronto Press.

Coleman, G. \& Jandrić, P. (2019). Postdigital Anthropology: Hacks, Hackers, and the Human Condition. Postdigital Science and Education, 1(2), 525-550. DOI: https://doi.org/10.1007/s42438-019-00065-8.

Cox, G. (2014). Prehistories of the post-digital: or, some old problems with post-anything. A Peer-Reviewed Journal About, 3(1), 4-7. DOI: https://doi .org/10.7146/aprja.v3i1.116087

Crary, J. (2013). 24/7: late capitalism and the ends of sleep. London: Verso.

Dall'Alba, G., \& Barnacle, R. (2007). An ontological turn for higher education. Studies in Higher Education, 32(6), 679-691. DOI: https://doi .org/10.1080/03075070701685130

Dastin, J. (2018, 10 October). Amazon scraps secret AI recruiting tool that showed bias against women. Reuters Business News. Retrieved from https://www.reuters.com/article/us-amazon-com-jobs-automation-insight /amazon-scraps-secret-ai-recruiting-tool-that-showed-bias-against -women-idUSKCN1MK08G

Deleuze, G., \& Guattari, F. (1988). A thousand plateaus: capitalism and schizophrenia. London: Continuum.

Duncan, E. (2018, 5 May). Review: bullshit jobs: a theory by David Graeber-quit now, your job is pointless. The Times. Retrieved from https://www.thetimes .co.uk/article/review-bullshit-jobs-a-theory-by-david-graeber-quit-now -your-job-is-pointless-9tk218jrq

Edmonds, D. (2015, 28 May). More than half of college faculty are adjuncts: should you care? Retrieved from https://www.forbes.com/sites/noodle education/2015/05/28/more-than-half-of-college-faculty-are-adjuncts -should-you-care/\#5407f4016005

Ellul, J. (1964). The technological society. New York: Vintage Books.

Eubanks, V. (2018). Automating inequality: how high-tech tools profile, police, and punish the poor. New York: St. Martin's Press.

Falconer, L. (2019). Review of Savin-Baden M. (2015). Rethinking learning in an age of digital fluency: is being digitally tethered a new learning nexus? Abingdon: Routledge. 168 pp. ISBN: 9780415738187. Postdigital Science and Education, 1(1), 244-246. DOI: https://doi.org/10.1007/s42438-018 -0014-7

Falkner, N. (2017) What happened to our promised leisure time? And will we find it in the smart city? The Conversation. Retrieved from https:// theconversation.com/what-happened-to-our-promised-leisure-time-and -will-we-find-it-in-the-smart-city- 83570

Feenberg, A. (2002). Transforming technology: a critical theory revisited. New York: Oxford University Press.

Ford, M. (2015). Rise of the robots: technology and the threat of a jobless future. New York: Basic Books. 
Freire, P. (1972). Pedagogy of the oppressed. Harmondsworth: Penguin Education Specials.

Frey, C. A., \& Osborne, M. A. (2013). The future of employment: how susceptible are jobs to computerisation? Retrieved from http://www.oxfordmartin .ox.ac.uk/downloads/academic/The_Future_of_Employment.pdf

Frey, C. A., \& Osborne, M. A. (2015). Technology at work: the future of innovation and employment. Retrieved from http://www.oxfordmartin.ox.ac.uk /downloads/reports/Citi_GPS_Technology_Work.pdf

Frude, N. (2019). Technological unemployment and psychological wellbeingcurse or benefit? In M. A. Peters, P. Jandrić \& A. J. Means (Eds.), Education and technological unemployment (pp. 95-113). Singapore: Springer.

Fukuyama, F. (1992). The end of history and the last man. New York: Free Press.

Gill, R. (2009). Breaking the silence: the hidden injuries of neo-liberal academia. In R. Flood \& R. Gill (Eds.), Secrecy and silence in the research process: feminist reflections. London: Routledge.

Ginsberg, B. (2010). The fall of the faculty: the rise of the all-administrative university and why it matters. Oxford: Oxford University Press.

Graeber, D. (2013). On the phenomenon of bullshit jobs: a work rant. Strikemag, 3. Retrieved from https://strikemag.org/bullshit-jobs

Graeber, D. (2018). Bullshit jobs: a theory. New York: Simon \& Schuster.

Haraway, D. (1991). A cyborg manifesto: science, technology, and socialistfeminism in the late twentieth century. In D. Haraway (Ed.), Simians, cyborgs and women: the reinvention of nature. New York: Routledge.

Hartman, Y., \& Darab, S. (2012). A call for slow scholarship: a case study on the intensification of academic life and its implications for pedagogy. Review of Education, Pedagogy, and Cultural Studies, 34(1-2), 49-60. DOI: https:// doi.org/10.1080/10714413.2012.643740

Hayes, S. (2015) Encouraging the intellectual craft of living research: tattoos, theory and time. In P. Bartholomew, C. Guerin \& C. Nygaard (Eds.), Learning to research, researching to learn, London: Libri.

Hayes, S. (2017). Introducing the concept of a corresponding curriculum. In A. Horsted, J. Branch \& C. Nygaard (Eds.), Learning-centred curriculum design in higher education. Faringdon: Libri.

Hayes, S. (2018). Invisible labour: do we need to reoccupy student engagement policy? Learning and Teaching, 11(1), 19-34. DOI: https://doi.org/10.3167 /latiss.2018.110102

Hayes, S. (2019). The labour of words in higher education: is it time to reoccupy policy? Leiden: Brill Sense.

Heidegger, M. (1981). 'Only a God can save us': the Spiegel interview. In T. Sheehan (Ed.), Heidegger: the man and the thinker (pp. 45-67). Chicago, IL: Precedent Press.

Hempel, J. (2018, 5 September). Want to prove your business is fair? Audit your algorithm. Wired. Retrieved from https://www.wired.com/story/want-to -prove-your-business-is-fair-audit-your-algorithm/ 
Hooley, T. (2019). Career guidance and the changing world of work: contesting responsibilising notions of the future. In M. A. Peters, P. Jandrić \& A. J. Means (Eds.), Education and technological unemployment. Singapore: Springer.

Horkheimer, M., \& Adorno, T. W. (2002). Dialectic of enlightenment: philosophical fragments. Stanford, CA: Stanford University Press.

Huxley, A. (1932). Brave new world. London: Penguin.

Huxley, A. (1962). Island. New York and Evanston, IL: Harper \& Row.

IBM Research. (2018). AI and bias. Retrieved from https://www.research.ibm .com/5-in-5/ai-and-bias/

Jandrić, P. (2015). If you can't beat them join them. Les Cahiers de l'idiotie, 6(1), 295-303.

Jandrić, P. (2017). Learning in the age of digital reason. Rotterdam: Sense.

Jandrić, P. (2019). Welcome to Postdigital Science and Education! Postdigital Science and Education, 1(1), 1-3. DOI: https://doi.org/10.1007/s42438-018 $-0013-8$

Jandrić, P. (2019). The postdigital challenge of critical media literacy. International Journal of Critical Media Literacy, 1(1), 26-37. DOI: https://doi .org/10.1163/25900110-00101002

Jandrić, P., Knox, J., Besley, T., Ryberg, T., Suoranta, J., \& Hayes, S. (2018). Postdigital science and education. Educational Philosophy and Theory, 50(10), 893-899. DOI: https://doi.org/10.1080/00131857.2018.1454000

Jones, C. (2018). Experience and networked learning. In N. Bonderup Dohn, S. Cranmer, J. A. Sime, M. de Laat \& T. Ryberg (Eds.), Networked learning: reflections and challenges (pp. 39-56). Singapore: Springer International.

Kahneman, D. (2013). Thinking, fast and slow. New York: Farrar, Strauss \& Giroux. Koltay, T. (2015). Data literacy: in search of a name and identity. Journal of Documentation, 71(2), 401-415. DOI: https://doi.org/10.1108/JD-02-2014 $-0026$

Krugman, P. (2013, 13 June). Sympathy for the Luddites. The New York Times. Retrieved from https://www.nytimes.com/2013/06/14/opinion/krugman -sympathy-for-the-luddites.html

Land, N. (2014). Teleoplexy: notes on acceleration. In R. Mackay \& A. Avanessian (Eds.), Accelerate: the accelerationist reader (pp. 509-520). Berlin: Merve.

MacCarthy, M. (2014). Time to kill the tech job-killing myth. The Hill. Retrieved from http://thehill.com/blogs/congress-blog/technology/219224-time-to -kill-the-tech-job-killing-myth

Marinetti, F. T. (1919). The futurist manifesto. Retrieved from https://www .societyforasianart.org/sites/default/files/manifesto_futurista.pdf

Marx, K. \& Engels, F. (1976). Manifesto of the Communist Party. In Marx \& Engels collected works, Volume 6. Moscow: Progress Publishers.

McLaren, P. (2006). Ed. Rage and hope: interviews with Peter McLaren on war, imperialism, and critical pedagogy. New York: Peter Lang.

McLaren, P. (2015). Pedagogy of insurrection: from resurrection to revolution (education and struggle). New York: Peter Lang. 
Menadue, C. B., \& Cheer, K. D. (2017). Human culture and science fiction: a review of the literature, 1980-2016. SAGE Open, 7(3), 1-15. DOI: https:// doi.org/10.1177/2158244017723690

Meyer, J. (2009). Acoustics and the performance of music (5th edn.). New York: Springer-Verlag Science+Business Media. Translated by U. Hansen.

O'Keeffe, C. (2017). Economizing education: assessment algorithms and calculative agencies. E-Learning and Digital Media, 14(3), 123-137. DOI: https:// doi.org/10.1177/2042753017732503

Peters, M. A. (2017). Technological unemployment: educating for the fourth industrial revolution. Educational Philosophy and Theory, 49(1), 1-6. DOI: https://doi.org/10.1080/00131857.2016.1177412

Peters, M. A., \& Besley, T. (2018). Critical philosophy of the postdigital. Postdigital Science and Education, 1(1), 29-42. DOI: https://doi.org/10.1007 /s42438-018-0004-9

Peters, M. A., \& Jandrić, P. (2018a). Education and technological unemployment in the fourth industrial revolution. In S. Crump, A. Drew \& G. Redding (Eds.), Oxford handbook of comparative higher education systems and university management. Oxford: Oxford University Press.

Peters, M. A., \& Jandrić, P. (2018b). The digital university: a dialogue and manifesto. New York: Peter Lang.

Peters, M. A., \& Jandrić, P. (2018c). Neoliberalism and the university. In D. Cahill, M. Cooper, M. Koenings \& D. Primrose (Eds.), SAGE handbook of neoliberalism (pp. 553-564). London: SAGE.

Peters, M. A., Jandrić, P., \& Hayes, S. (2018). The curious promise of educationalising technological unemployment: what can places of learning really do about the future of work? Educational Philosophy and Theory, 51(3), 242-254. https://doi.org/10.1080/00131857.2018.1439376

Peters, M. A., Jandrić, P., \& Means, A. J. (2019). Eds. Education and technological unemployment. Singapore: Springer.

Ricardo, D. (1817). On the principles of political economy and taxation. London: John Murray.

Ritzer, G., Jandrić, P., \& Hayes, S. (2018). Prosumer capitalism and its machines. Open Review of Educational Research, 5(1), 113-129. DOI: https://doi.org /10.1080/23265507.2018.1546124

Rogoff, K. (2012). King Ludd is still dead. Project Syndicate. Retrieved from https://www.project-syndicate.org/commentary/technology-unemploy ment-jobs-internet-by-kenneth-rogoff

Rose, L. (2015). Resistance is futile: cognitive dissonance, temporal refusal, and the e-learning environment as cyborg. E-Learning and Digital Media, 12(3-4), 315-326. DOI: https://doi.org/10.1177/2042753015571053

Savin-Baden M. (2015). Rethinking learning in an age of digital fluency: is being digitally tethered a new learning nexus? Abingdon: Routledge.

Sellar, S. (2019). Acceleration, Automation and Pedagogy: How the Prospect of Technological Unemployment Creates New Conditions for Educational 
Thought. In M.A. Peters, P. Jandrić, \& A. Means (Eds.), Education and Technological Unemployment (pp. 131-144). Singapore: Springer. DOI: https:// doi.org/10.1007/978-981-13-6225-5_9

Skidelsky, R. (2013). The rise of the robots. Project Syndicate. Retrieved from https://www.project-syndicate.org/commentary/the-future-of-work-in-a -world-of-automation-by-robert-skidelsky

Skidelsky, R. (2014). Death to machines? Project Syndicate. Retrieved from https://www.project-syndicate.org/commentary/robert-skidelsky-revisits -the-luddites--claim-that-automation-depresses-real-wages

Spielberg, S. (2002). Minority report [motion picture]. Los Angeles: 20th Century Fox, DreamWorks Pictures, Amblin Entertainment and Blue Tulip Productions.

Srnicek, N., \& Williams, A. (2015). Inventing the future: postcapitalism and a world without work. London and New York: Verso Books.

Stiegler, B. (1998). Technics and time, 1: the fault of Epimetheus. Stanford, CA: Stanford University Press.

Summers, L. (2014, 7 July). Lawrence H. Summers on the economic challenge of the future: jobs. The Wall Street Journal. Retrieved from http://www.wsj .com/articles/lawrence-h-summers-on-the-economic-challenge-of-the -future-jobs-1404762501

Tahir, T. (2010, 30 March). The irresistible rise of academic bureaucracy. The Guardian. Retrieved from https://www.theguardian.com/education/2010 /mar/30/academic-bureaucracy-rise-managers-higher-education

Thompson, D. (2015). A world without work. The Atlantic, 316(1), 50-61.

Vostal, F. (2013, 20 November). Should academics adopt an ethic of slowness or ninja-like productivity? In search of scholarly time. Retrieved from http://blogs .lse.ac.uk/impactofsocialsciences/2013/11/20/in-search-of-scholarly-time/

Williams, A., \& Srnicek, N. (2013, 14 May). \#ACCELERATE MANIFESTO for an accelerationist politics. Critical Legal Thinking. Retrieved from http://criticallegalthinking.com/2013/05/14/accelerate-manifesto-for-an -accelerationist-politics/

Williamson, B. (2017). Who owns educational theory? Big data, algorithms and the expert power of education data science. E-Learning and Digital Media, 14(3), 105-122. DOI: https://doi.org/10.1177\%2F2042753017731238

World Economic Forum. (2016). The future of jobs: employment, skills and workforce strategy for the fourth industrial revolution. Geneva: World Economic Forum. 